\title{
G-CSF does not influence C2C12 myogenesis despite receptor expression in healthy and dystrophic skeletal muscle
}

\author{
Craig R. Wright ${ }^{1}$, Erin L. Brown ${ }^{1}$, Paul A. Della-Gatta ${ }^{1}$, Alister C. Ward ${ }^{2}$, Gordon S. Lynch ${ }^{3}$ and \\ Aaron P. RusselI ${ }^{1 *}$
}

${ }^{1}$ Centre for Physical Activity and Nutrition, School of Exercise and Nutrition Sciences, Deakin University, Burwood, VIC, Australia

${ }^{2}$ Molecular and Medical Research SRC, School of Medicine, Deakin University, Waurn Ponds, VIC, Australia

${ }^{3}$ Basic and Clinical Myology Laboratory, Department of Physiology, The University of Melbourne, VIC, Australia

\section{Edited by:}

Steven P. Jones, University of

Louisville, USA

Reviewed by:

John Hollander, West Virginia

University School of Medicine, USA

Ashok Kumar, University of

Louisville, USA

*Correspondence:

Aaron P. Russell, Centre for Physical Activity and Nutrition, School of

Exercise and Nutrition Sciences,

Deakin University, 221 Burwood

Hwy, Burwood, VIC 3125, Australia e-mail: aaron.russell@deakin.edu.au
Granulocyte-colony stimulating factor (G-CSF) increases recovery of rodent skeletal muscles after injury, and increases muscle function in rodent models of neuromuscular disease. However, the mechanisms by which G-CSF mediates these effects are poorly understood. G-CSF acts by binding to the membrane spanning G-CSFR and activating multiple intracellular signaling pathways. Expression of the G-CSFR within the haematopoietic system is well known, but more recently it has been demonstrated to be expressed in other tissues. However, comprehensive characterization of G-CSFR expression in healthy and diseased skeletal muscle, imperative before implementing G-CSF as a therapeutic agent for skeletal muscle conditions, has been lacking. Here we show that the G-CSFR is expressed in proliferating $\mathrm{C} 2 \mathrm{C} 12$ myoblasts, differentiated C2C12 myotubes, human primary skeletal muscle cell cultures and in mouse and human skeletal muscle. In $m d x$ mice, a model of human Duchenne muscular dystrophy (DMD), G-CSF mRNA and protein was down-regulated in limb and diaphragm muscle, but circulating G-CSF ligand levels were elevated. G-CSFR mRNA in the muscles of $m d x$ mice was up-regulated however steady-state levels of the protein were down-regulated. We show that G-CSF does not influence $\mathrm{C}_{2} \mathrm{C}_{12}$ myoblast proliferation, differentiation or phosphorylation of Akt, STAT3, and Erk1/2. Media change alone was sufficient to elicit increases in Akt, STAT3, and Erk1/2 phosphorylation in $\mathrm{C}_{2} \mathrm{C}_{12}$ muscle cells and suggest previous observations showing a G-CSF increase in phosphoprotein signaling be viewed with caution. These results suggest that the actions of G-CSF may require the interaction with other cytokines and growth factors in vivo, however these data provides preliminary evidence supporting the investigation of G-CSF for the management of muscular dystrophy.

Keywords: G-CSF, cytokine receptor, skeletal muscle, duchenne muscular dystrophy, $\mathbf{m d x}, \mathbf{C 2 C 1 2}$, proliferation, differentiation

\section{INTRODUCTION}

Skeletal muscle atrophy is a devastating condition that is characteristic of neuromuscular diseases such as Duchenne muscular dystrophy (DMD) and many chronic diseases including cancer, heart disease, chronic obstructive pulmonary disease (COPD), sepsis and AIDS (Jagoe and Goldberg, 2001). As a result, skeletal muscle atrophy is a strong predictor of morbidity and mortality associated with cardiovascular, musculoskeletal, nervous, renal, and respiratory diseases, as well as cancer, which are among the leading causes of death worldwide (Murray and Lopez, 1997; DalRe, 2011). Therefore, development of therapeutic strategies to reduce muscle wasting while enhancing muscle regeneration and growth is required to improve clinical outcomes.

Granulocyte-colony stimulating factor (G-CSF, encoded by CSF3) is a cytokine that stimulates haematopoietic stem cell mobilization, myelopoiesis, and particularly the production and activation of neutrophils (Roberts, 2005). G-CSF exerts its effects by binding to the G-CSF receptor (G-CSFR, encoded by CSF3R) on target cells. G-CSFR is highly expressed on haematopoietic stem cells and various myeloid cells (Nagata and Fukunaga, 1991), but also on other cell types including neural tissue (Yata et al., 2007; Pitzer et al., 2008, 2010), liver stem cells (Piscaglia et al., 2007) and cardiac muscle (Li et al., 2006, 2007; Takano et al., 2006; Ueda et al., 2006; Shimoji et al., 2010). These observations suggest that G-CSF may regulate cells outside of the haematopoietic system.

Skeletal muscle precursor cells, retinal muscle, and muscles of the tongue have been shown to express G-CSFR during embryonic development (Kirsch et al., 2008; Oishi et al., 2008). More recently, G-CSFR expression has been also reported on proliferating $\mathrm{C} 2 \mathrm{C} 12$ myoblasts using immunofluorescence and Western blotting (Hara et al., 2011). However, mRNA and protein levels of G-CSF and the G-CSFR have not been investigated in differentiating $\mathrm{C} 2 \mathrm{C} 12$ myoblasts, terminally differentiated $\mathrm{C} 2 \mathrm{C} 12$ myotubes, 
primary skeletal muscle cells or mature muscle. Both G-CSF and G-CSFR are dysregulated in many disease states. For example, ovarian cancers express G-CSFR (Ninci et al., 2000; Savarese et al., 2001), which contributes to cell survival and migration (Kumar et al., 2014), and bladder cancers express G-CSFR during the early stages of their development (Tachibana et al., 1997; Chakraborty et al., 2004, 2006), despite these tissues not normally expressing G-CSFR. In patients with ALS, G-CSF levels are elevated in the cerebrospinal fluid, while G-CSFR levels are decreased (Tanaka et al., 2006). In contrast, mouse models of ALS show increased levels of both and G-CSF/G-CSFR in neural tissue (Pitzer et al., 2008).

Treatment with G-CSF attenuates the severity of ischemic heart disease, acute myocardial infarction and chronic heart failure by stimulating the proliferation of cardiomyocytes ( $\mathrm{Li}$ et al., 2006, 2007; Takano et al., 2006; Ueda et al., 2006). In skeletal muscle, G-CSF treatment improves force recovery, activates satellite cells and increases muscle mass following crush injury (Stratos et al., 2007). G-CSF treatment increases muscle repair following a local cardiotoxin (CTX) injection in mice (Naito et al., 2009) and increases muscle function in mouse models of amyotrophic lateral sclerosis (ALS) (Pitzer et al., 2008). Eight weeks of G-CSF treatment $(30 \mu \mathrm{g} / \mathrm{kg} /$ day $)$ increased Akt phosphorylation in neural tissue of ALS mice (Pitzer et al., 2008). G-CSF also increased Akt phosphorylation in regenerating skeletal muscle after myotoxic injury (Naito et al., 2009). These observations support a role for G-CSF in improving muscle health following injury. Therefore, understanding the molecular mechanisms for G-CSF action in skeletal muscle remains essential for implementing G-CSF as therapeutic agent for skeletal muscle disease.

The aims of this study were to firstly, to characterize the mRNA and protein expression of G-CSF and G-CSFR during muscle cell differentiation and in healthy and diseased mature skeletal muscle. The second aim was to determine the role of G-CSF in C2C12 myoblast differentiation and its ability to phosphorylate several proteins involved in muscle cells differentiation including Akt, STAT3, Erk-1, and Erk-2.

\section{METHODS}

\section{TISSUE EXTRACTIONS}

The human muscle biopsy procedure was approved by the Deakin University Human Research Ethics Committee in accordance with the Declaration of Helsinki (2000). Skeletal muscle samples were obtained under local anaesthesia (1\% Xylocaine) from the belly of the vastus lateralis muscle using a percutaneous needle biopsy technique (Bergstrom, 1975), modified to include suction (Evans et al., 1982). Following a small incision through the skin, muscle biopsies were taken using a Bergstrom needle. Muscle samples were snap frozen in liquid nitrogen for RNA and protein extraction, with fresh muscle used for primary myoblast cultures.

The diaphragm and tibialis anterior (TA) muscles from 8 to 9 week old C57BL/10 and $m d x$ mice were excised as part of a previously published study (Gehrig et al., 2012). Whole blood was obtained by cardiac puncture and immediately centrifuged at $4000 \mathrm{rpm}$ for $5 \mathrm{~min}$, with the upper plasma phase transferred to a sterile Eppendorf tube and frozen at $-80^{\circ} \mathrm{C}$. Male mice were used for all experiments. All experiments were approved by the
Animal Ethics Comitte (AEC), The University of Melbourne and conducted in accordance with the Australian code of practice for the care and use of animals for scientific purposes, as stipulated by the National Health and Medical Research Council (Australia).

\section{CELl CULTURE}

For myoblast proliferation experiments, $\mathrm{C} 2 \mathrm{C} 12$ myoblasts (American Type Culture Collection, ATCC, Manassas, VA) were seeded at a density of 50 cells per $\mathrm{mm}^{2}$ and incubated at $37^{\circ} \mathrm{C}$, $5 \% \mathrm{CO}_{2}$ in growth media consisting of high glucose Dulbecco's Modified Eagle's Medium (DMEM) supplemented with 10\% (v/v) foetal bovine serum (FBS) (Invitrogen, Carlsbad, CA). For myotube differentiation experiments, $\mathrm{C} 2 \mathrm{C} 12$ were seeded at a density of 150 cells per $\mathrm{mm}^{2}$ and incubated as above. G-CSF was used at concentrations between 0.4 and $100 \mathrm{ng} / \mathrm{ml}$ as published previously (Ward et al., 1999).

BAF/3 [G] cells, a pro-B mouse cell line stably transfected with G-CSFR (Ward et al., 1999), were maintained at $37^{\circ} \mathrm{C}, 5 \% \mathrm{CO}_{2}$ in DMEM containing 10\% (v/v) FBS and 10\% (v/v) conditioned WEHI-3B medium. HEK293T cells (ATCC) were maintained at $37^{\circ} \mathrm{C}, 5 \% \mathrm{CO}_{2}$ in high glucose DMEM supplemented with $10 \%$ $(\mathrm{v} / \mathrm{v})$ FBS (Invitrogen). Human primary muscle cell cultures were established as previously described in our laboratory (Wallace et al., 2011).

\section{Proliferation}

Cells were allowed to attach overnight before being incubated with G-CSF at the desired concentration in DMEM supplemented with either $10 \%(\mathrm{v} / \mathrm{v})$ FBS or $2 \%(\mathrm{w} / \mathrm{v})$ BSA, which was replenished every $24 \mathrm{~h}$. After 24, 48, 72, and $96 \mathrm{~h} \mathrm{C} 2 \mathrm{C} 12$ myoblasts were incubated with $0.1 \mu \mathrm{g} / \mathrm{ml} \mathrm{4}$, 6 -Diamidino-2-phenylindole dihydrochloride (DAPI) (Sigma-Aldrich, Castle Hill, NSW, Australia) for $10 \mathrm{~min}$ at room temperature. Images were obtained using the Olympus Fluoview FV10i confocal laser scanning microscope with dedicated software at a $10 \mathrm{x}$ magnification. A minimum of ten images per group were analyzed using ImageJ Software (National Institutes of Health, Bethesda, MA) to quantify the number of nuclei per image.

Myoblasts were assayed for DNA synthesis using a 5-bromo2 '-deoxyuridine (BrdU) Labeling and Detection Kit III (Roche, Castle Hill, NSW, Australia) according to the manufacturer's protocol. Briefly, following 24 and $48 \mathrm{~h}$ of BrdU labeling $(10 \mu \mathrm{M})$, myoblasts were fixed in $70 \%$ ethanol in $0.5 \mathrm{M} \mathrm{HCl}$ at $-20^{\circ} \mathrm{C}$ for $30 \mathrm{~min}$. Following a series of PBS washes containing 10\% FBS, cells were incubated with the supplied nucleases at $37^{\circ} \mathrm{C}$ in the absence of $\mathrm{CO}_{2}$ for $30 \mathrm{~min}$. Cells were again washed and incubated with anti-BrdU-POD Fab fragments for $30 \mathrm{~min}$ at $37^{\circ} \mathrm{C}$. After a final series of washes, peroxidase substrate with substrate enhancer was added to the wells and the substrate left to develop in the dark for $5 \mathrm{~min}$ before the absorbance was determined at a wavelength of $405 \mathrm{~nm}$.

\section{Differentiation}

When myoblasts were confluent, DMEM containing $2 \%$ $\mathrm{HS} \pm \mathrm{G}$-CSF was added to induce differentiation. Images were obtained every $24 \mathrm{~h}$ for 4 days using an Olympus IX70 microscope (Olympus, Mt Waverly, VIC, Australia), and an attached 
DS-U3 microscope camera with NIS-Elements imaging software (Nikon Instruments Inc., Melville, NY) to assess differentiation. At the same time points RNA was extracted from the cells and RT-PCR was performed on genetic markers of differentiation. The media \pm G-CSF was replenished every $24 \mathrm{~h}$ throughout the experiment.

\section{RNA EXTRACTION, REVERSE TRANSCRIPTION AND REAL TIME POLYMERASE CHAIN REACTION (REAL-TIME PCR)}

TRI-Reagent (Ambion Inc., Austin TX) was used to extract RNA from each cell culture sample or approximately $20-40 \mathrm{mg}$ wet weight of muscle, with RNA concentrations determined using a NanoDrop ${ }^{\circledR}$ ND-1000 spectrophotometer (NanoDrop products, Wilmington, DE). The RNA was reverse transcribed (RT) to synthesize first strand cDNA using a high-capacity RNA-cDNA reverse transcription kit (Applied Biosystems, Foster City, CA). Each sample was incubated with one unit of ribonuclease $\mathrm{H}$ (RNAse $\mathrm{H}$ ) (Invitrogen) at $37^{\circ} \mathrm{C}$ for $30 \mathrm{~min}$ following reverse transcription.

A mixture containing $0.5 \times \mathrm{SYBR}^{\circledR}$ Green PCR Master Mix (Applied Biosystems) and the forward and reverse primers for the gene of interest (Table 1) was added to $25 \mathrm{ng}$ cDNA. Real-time polymerase chain reaction (Real-Time PCR was performed using a Stratagene Mx3000p QPCR System (Stratagene, La, CA) run by MxPro QPCR Software (Stratagene). All primers were used at $300 \mathrm{nM}$ with an annealing temperature of $60^{\circ} \mathrm{C}$.

In some experiments, the resulting PCR products were separated on a $1.8 \%$ agarose gel containing $0.5 \times \mathrm{SYBR}^{\circledR}$ Safe DNA Gel Stain (Invitrogen). Images were captured using the Kodak Gel Logic 112 image station (Kodak Scientific Imaging Systems, Rochester, NY) under $302 \mathrm{~nm}$ UV light. The cDNA fragments were purified using the QIAquick Gel Extraction Kit (QIAGEN, Clifton Hill, VIC, Australia) according to the manufacturer's protocol. The purified cDNA from BAF/3 $[\mathrm{G}]$ and $\mathrm{C} 2 \mathrm{C} 12$ myoblasts and $\mathrm{C} 2 \mathrm{C} 12$ myotubes was sequenced by the Australian Genome Research Facility (AGRF, Parkville, VIC, Australia).

\section{PROTEIN EXTRACTION AND WESTERN BLOT ANALYSIS}

Myoblasts and myotubes were serum starved in DMEM (Invitrogen) for $4 \mathrm{~h}$ followed by stimulation with serum free media \pm G-CSF. Total protein was extracted after 5, 10, 15, 30, and $90 \mathrm{~min}$ and phosphorylation was compared to basal levels following $4 \mathrm{~h}$ of serum starvation.
Total protein was extracted from muscle tissue and cell culture using 1x radioimmunoprecipitation (RIPA) buffer (Millipore, North Ryde, NSW) with $1 \mu \mathrm{L} / \mathrm{mL}$ protease inhibitor cocktail (Sigma-Aldrich, Castle Hill, NSW) and $10 \mu \mathrm{L} / \mathrm{mL}$ Halt Phosphatase Inhibitor Single-Use Cocktail (Thermo Scientific, Rockford, IL). Samples were centrifuged at 13,000 rpm for $15 \mathrm{~min}$ with the protein concentration of the supernatant determined from the development of a standard curve using the bicinchoninic acid (BCA) assay Protein Assay Kit (Pierce Biotechnology, Rockford, IL) according to the manufacturer's protocol.

Protein deglycosylation was performed using the PNGase F (New England Biolabs, Ipswich, MA) according to the manufacturer's protocol. In brief, $20 \mu \mathrm{g}$ total protein was denatured in $1 \times$ glycoprotein denaturing buffer at $100^{\circ} \mathrm{C}$ for $10 \mathrm{~min}$. Following denaturing $1 \times$ G7 reaction buffer, $2 \mu \mathrm{l} 10 \%(\mathrm{v} / \mathrm{v}) \mathrm{NP}-40$ and $2 \mu \mathrm{l}$ PNGase $\mathrm{F}$ was added to the protein sample. The sample was incubated using a water bath at $37^{\circ} \mathrm{C}$ for $1 \mathrm{~h}$. The samples were frozen at $-80^{\circ} \mathrm{C}$ for Western blot analysis.

Electrophoresis was performed using a $4-12 \% \mathrm{NuPAGE}^{\circledR}$ Novex Bis-Tris Gel in NuPAGE ${ }^{\circledR}$ SDS MOPS Running Buffer (Invitrogen). Proteins were transferred to a PVDF membrane (Millipore) in a Bjerrum buffer containing $50 \mathrm{mM}$ Tris, $17 \mathrm{mM}$ glycine and $10 \%(\mathrm{v} / \mathrm{v})$ methanol. The membranes were blocked with 5\% BSA in PBS, after which they were incubated overnight at $4^{\circ} \mathrm{C}$ with anti-G-CSFR antibody (1:1000) (Santa Cruz Biotechnology, USA), anti-phospho-Akt (Ser473), anti-phospho-STAT3 (Tyr705), anti-phospho-Erk1/2 (Thr202/Tyr204), anti-Akt, anti-STAT3 and and anti-Erk1/2 (Cell Signaling Technology, Denvers, MA) diluted in PBS containing $5 \%$ BSA. Following washing, the membranes were incubated with goat anti-rabbit IgG antibody (1:5000) labeled with an infraredfluorescent $800 \mathrm{~nm}$ dye (Alexa Fluor ${ }^{\circledR}$ 800, Invitrogen) in PBS containing 50\% Odyssey ${ }^{\circledR}$ blocking buffer (LI-COR Biosciences, Lincoln, USA) and $0.01 \%(\mathrm{w} / \mathrm{v})$ SDS. After washing, the proteins were exposed on an Odyssey ${ }^{\circledR}$ Infrared Imaging System (LI-COR). Anti-GAPDH antibody (1:5000) (G8795, SigmaAldrich, Australia) and rabbit anti-mouse IgG antibody labeled with an infrared-fluorescent $680 \mathrm{~nm}$ dye (Alexa Fluor ${ }^{\circledR} 680$, Invitrogen) was used as a loading control.

\section{CYTOKINE ANALYSIS}

A Milliplex assay (Millipore) was used to analyse G-CSF protein expression in the skeletal muscle and plasma samples following the manufacturer's protocol (Millipore). Briefly, the samples and

Table 1 | Human and mouse PCR primer sequences.

\begin{tabular}{|c|c|c|c|}
\hline Primer & Accession no. & Sense $\left(5^{\prime}-3^{\prime}\right)$ & Anti-sense $\left(5^{\prime}-3^{\prime}\right)$ \\
\hline CSF3R (G-CSFR) & NM_000760 & CCTGCATCATCAAGCAGAAC & AGTTCAGGAAGCAGGAGAGA \\
\hline Csf3r (G-CSFR) & NM_007782 & TCATGGCCACCAGTCGAGC & CACGCTGGAGTCCCAGAAG \\
\hline Myh7 & NM_080728 & ACCCTCAGGTGGCTCCGAGA & TGCAGCCCCAAATGCAGCCA \\
\hline Myh2 & NM_001039545 & GAGCAAAGATGCAGGGAAAG & TAAGGGTTGACGGTGACACA \\
\hline Myh1 & NM_030679 & GGACCCACGGTCGAAGTTGCA & GGAACTCATGGCTGCGGGCT \\
\hline
\end{tabular}


standards were added to a 96 well plate containing premixed beads coated with G-CSF antibody. Following a $30 \mathrm{~min}$ incubation plates were washed three times then incubated with pre-mixed detection antibodies. Wells were then washed and incubated with streptavidin-phycoerythrin. After a final series of washes samples were resuspended in $125 \mu$ l of assay buffer. The plate was read on the Bio-Plex Suspension Array System (V.5.0, Bio-Rad). For skeletal muscle, samples were extracted according to the protein extraction method described above and diluted to $1000 \mu \mathrm{g} / \mathrm{ml}$ prior to the assay. Plasma samples were run undiluted. Intra-assay coefficient of variation (CV\%) was $4.2 \%$ for the plasma and $7.1 \%$ for the diaphragm homogenate.

\section{STATISTICAL ANALYSIS}

Statistical analysis was performed using GraphPad Prism 4.1 (GraphPad Software, San Diego, CA). Comparisons between wild type control and $m d x$ mice were made using an unpaired Student t-test. Significance was set at $p<0.05$ for all statistical tests with data represented as mean \pm SEM.

For measurements of proliferation a One-Way ANOVA was used to determine the interaction between treatment concentration $(0,0.4,4,40$, and $100 \mathrm{ng} / \mathrm{ml} \mathrm{G-CSF})$ at each time point. For BrdU analysis a Two-Way ANOVA was used to determine the interaction between G-CSF concentration $(0,0.4,4,40$, and $100 \mathrm{ng} / \mathrm{ml} \mathrm{G-CSF}$ ) and treatment group (under normal growth conditions vs. serum depletion). Newman-Keuls Multiple
Comparison Test was used to determine differences between groups with significance set at $p<0.05$.

For measurements of differentiation a One-Way ANOVA was used to determine the interactions of time (day 1, 2, 3, and 4). Furthermore, a One-Way ANOVA was used to determine the interaction between treatment concentrations $(0,0.4,4,40$, and $100 \mathrm{ng} / \mathrm{ml} \mathrm{G-CSF)}$ at each day. Newman-Keuls Multiple Comparison Test was used to determine differences between groups with significance set at $p<0.05$.

For densitometry analysis a One-Way ANOVA was used to determine the interaction of time $(0,5,10,15,30,60$, and $90 \mathrm{~min})$ at the given concentration of G-CSF treatment. Furthermore, a Two-Way ANOVA was used to determine an interaction between time (0, 5, and $15 \mathrm{~min}$ ) and treatment (Control and G-CSF). Newman-Keuls Multiple Comparison Test was used to determine differences between groups with significance set at $p<0.05$.

\section{RESULTS}

\section{IDENTIFICATION OF G-CSFR IN SKELETAL MUSCLE}

To investigate the expression of the genes encoding G-CSF and GCSFR, intron-spanning primers described in Table 1 were used for Real-Time PCR. Fragments of the expected $\sim 200$ base pairs were observed in both mouse and human myoblasts, myotubes and tissue homogenates (Figure 1A). Sequencing of these products confirmed that they represented bone fide sequences, confirming expression of the G-CSFR in myoblasts and myotubes (Table S1).

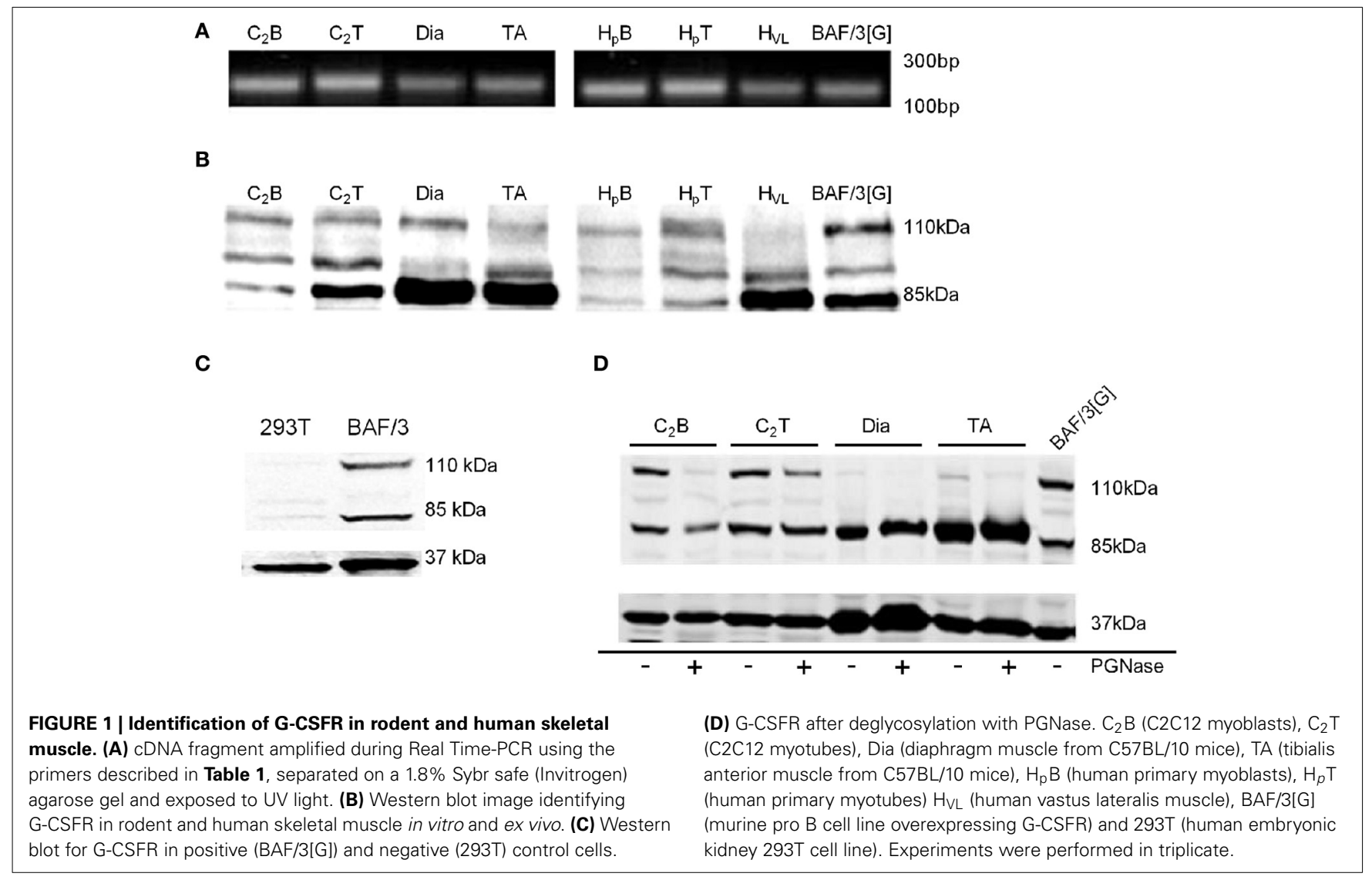


Using a polyclonal antibody raised against amino acids 25-200 of human G-CSFR (Santa Cruz, Delaware, CA), Western blot analysis confirmed expression of G-CSFR protein in mouse $\mathrm{C} 2 \mathrm{C} 12$ and human primary myoblasts and myotubes, as well as in mouse and human skeletal muscle (Figure 1B). Multiple bands were observed, consistent with multiple glycosylated forms of the receptor. Similar forms were observed in BAF/3 cells stably expressing the G-CSFR protein used as a positive control (Figures 1B,C), but not in HEK293T cells used as a negative control since they are known not to express G-CSFR (Debruin et al., 2010) (Figure 1C). Treatment of protein lysates with PGNase reduced the band intensity at $110 \mathrm{kDa}$ in $\mathrm{C} 2 \mathrm{C} 12$ myoblasts, $\mathrm{C} 2 \mathrm{C} 12$ myotubes and in mouse and human skeletal muscle homogenates, confirming the $110 \mathrm{kDa}$ band as a glycosylated form of the G-CSFR protein (Figure 1D).

To investigate the expression of the G-CSFR throughout myotube development, differentiation of confluent $\mathrm{C} 2 \mathrm{C} 12$ myoblasts was induced by serum depletion. C2C12 cells formed visible myotubes after 4 days (Figure 2A), with differentiation confirmed by measuring various myosin heavy chain (Myh7, 4, 2, 1) mRNA levels, known markers of muscle cell differentiation (Brown et al., 2012). All Myh mRNAs were elevated by day $3(p<0.01)$ and day $4(p<0.001)$ when compared to day 0 (Figure 2B). G-CSF mRNA transiently increased by $20 \%$
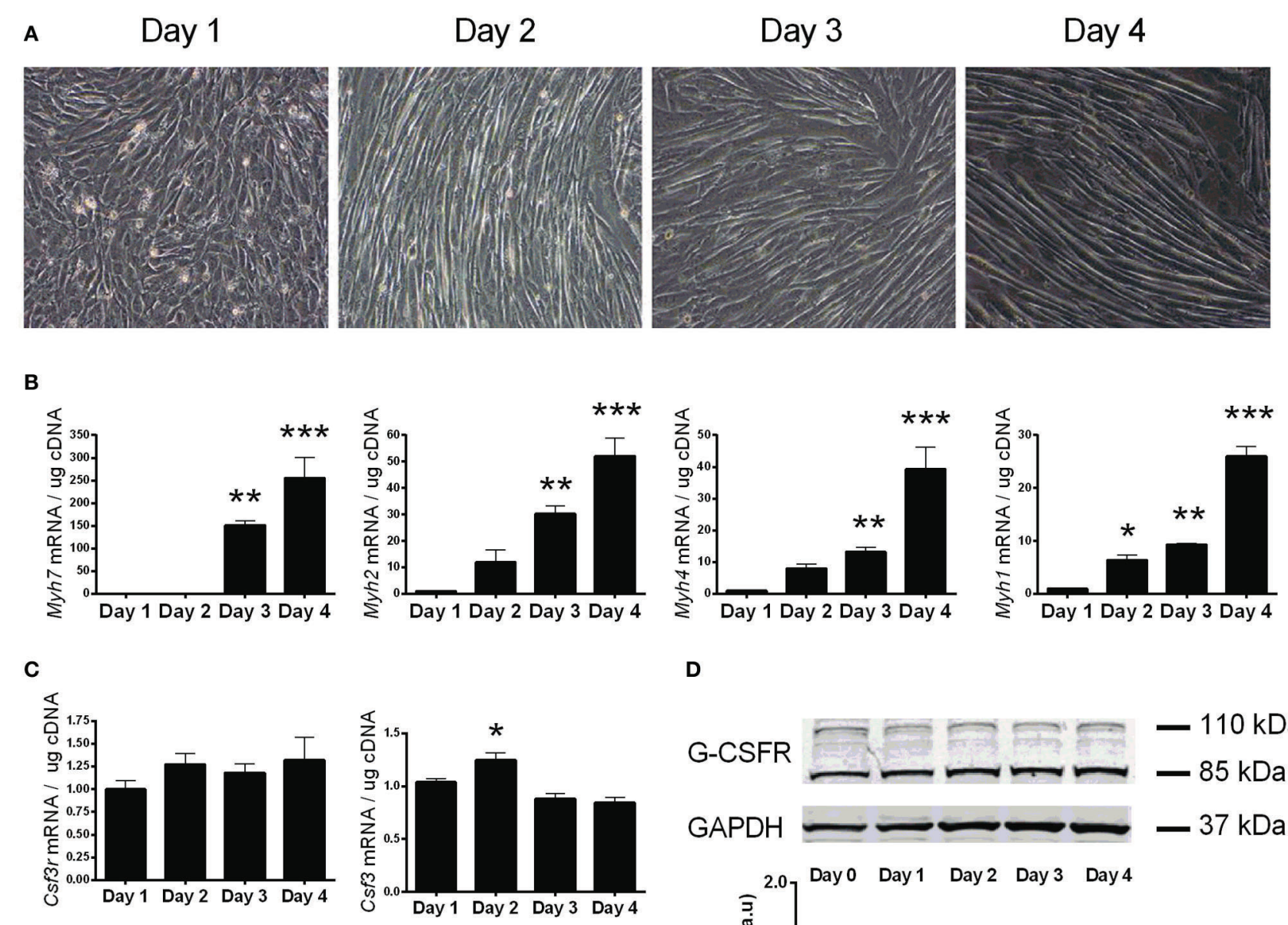

D
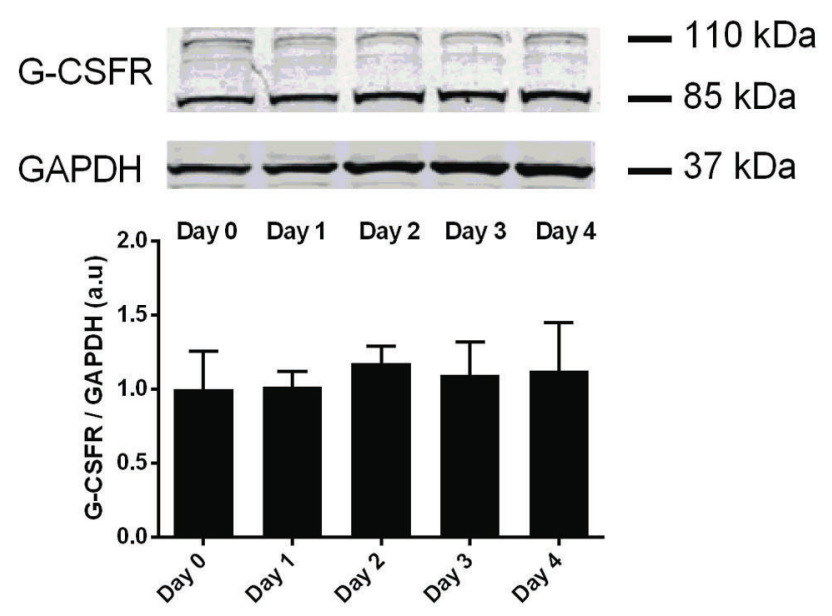

FIGURE 2 | Characterization of G-CSF and G-CSFR during C2C12 myogenesis. (A) Representative images of $\mathrm{C} 2 \mathrm{C} 12$ during differentiation. (B) Expression of myosin heavy chain genes (Myh7, 2, 4, 1) during following differentiation of $\mathrm{C} 2 \mathrm{C} 12$ cultures. (C) G-CSF (Csf3) and G-CSFR (Csf3r) mRNA

expression and (D) G-CSFR protein expression during differentiation of C2C12 cultures. Day 0 represents near confluent myoblasts (>90\% confluent). Day 1 represents $24 \mathrm{~h}$ post serum withdrawal. mRNA is expressed as a fold change after Day $0(n=3) .{ }^{*} p<0.05,{ }^{* *} p<0.01$ and ${ }^{* * *} p<0.001$ 
$(p<0.05)$ at day 2 (Figure 2C), but no change in G-CSFR mRNA or protein levels was observed during differentiation (Figures 2C, D).

\section{THE REGULATION OF G-CSF AND G-CSFR IN MUSCLES FROM $m d x$ mice}

We next sought to examine whether the expression of G-CSF or its receptor were altered in dystrophic muscle, for which we used the $m d x$ mouse. G-CSF mRNA was reduced by approximately $70 \%$ in the TA $(p<0.001)$ and approximately $80 \%$ in the diaphragm muscles $(p<0.001)$ of $8-9$ week old $m d x$ mice compared to littermate controls (Figures 3A,B). In contrast G-CSFR mRNA levels were 8 -fold $(p<0.01)$ and $>15$-fold $(p<0.001)$ higher in the TA and diaphragm muscles, respectively, of $m d x$ mice compared with control mice (Figures 3C,D). Circulating G-CSF levels were also significantly elevated in $m d x$ mice compared with littermate controls $(p<0.05)$ (Figure 4A). However, the G-CSF protein was also reduced in the diaphragm muscle $(p<0.001)$ (Figure 4B), consistent with the G-CSF mRNA analysis. Levels of the G-CSF ligand were below the detectable limits of the assay in the TA muscle (data not shown). In contrast to levels of the G-CSFR mRNA, the G-CSFR protein was significantly reduced in both the TA $(p<0.05)$ and diaphragm muscle $(p<0.05)$ of $m d x$ mice (Figures 4C,D).

\section{THE ROLE OF G-CSF IN PROLIFERATION, DIFFERENTIATION, AND PROTEIN SIGNALING IN C2C12 MYOBLASTS}

To investigate the effects of G-CSF on myoblast proliferation, myoblasts were enumerated by DAPI staining at $24 \mathrm{~h}$ intervals over $96 \mathrm{~h}$ (Supplementary Figures 1, 2). C2C12 myoblasts proliferated as expected, approximately doubling at 48 and $72 \mathrm{~h}$, reaching confluency and showing signs of spontaneous fusion at $96 \mathrm{~h}$ under normal growth conditions (Figure 5A). Slower proliferation rates were observed in serum depleted conditions over the first $48 \mathrm{~h}$ followed by the cessation of proliferation thereafter (Figure 5B). No changes in cell number was observed with the addition of G-CSF up to $100 \mathrm{ng} / \mathrm{ml}$ under normal or serum depleted conditions (Figure 5).

To confirm that G-CSF was not affecting proliferation, DNA synthesis was assayed by BrdU incorporation in $\mathrm{C} 2 \mathrm{C} 12$ myoblasts for 24 and $48 \mathrm{~h}$. In normal growth conditions $\mathrm{C} 2 \mathrm{C} 12$ myoblasts incorporated more BrdU into their cellular DNA compared to serum depleted cells. G-CSF treatment did not have any effect on BrdU incorporation at 24 and $48 \mathrm{~h}$ (Supplementary Figure 3 )

To examine the effects of G-CSF on myoblast differentiation G-CSF was added to $\mathrm{C} 2 \mathrm{C} 12$ myoblasts during myotube formation. $\mathrm{C} 2 \mathrm{C} 12$ cells formed visible myotubes after 4 days in the absence of G-CSF, as expected, with no visible differences observed in G-CSF treated cells (Figure 6A). G-CSF also had no effect on the level of expression of Myh7, Myh4, Myh2, and Myh1 which all increased during differentiation (Figures 6B-E), nor on the myogenic regulatory factors $\mathrm{MyoD}$ and myogenin during C2C12 differentiation (data not shown).

It has previously been shown that Akt and Erk1/2 phosphorylation were sensitive to the stress associated with changing media in cardiomyocytes (Sinclair et al., 2010). We also examined this in $\mathrm{C} 2 \mathrm{C} 12$ myoblasts, and observed that media changes also led to phosphorylation of both Akt and Erk1/2 in these cells (Figure 7). Therefore, to overcome the potential confounding
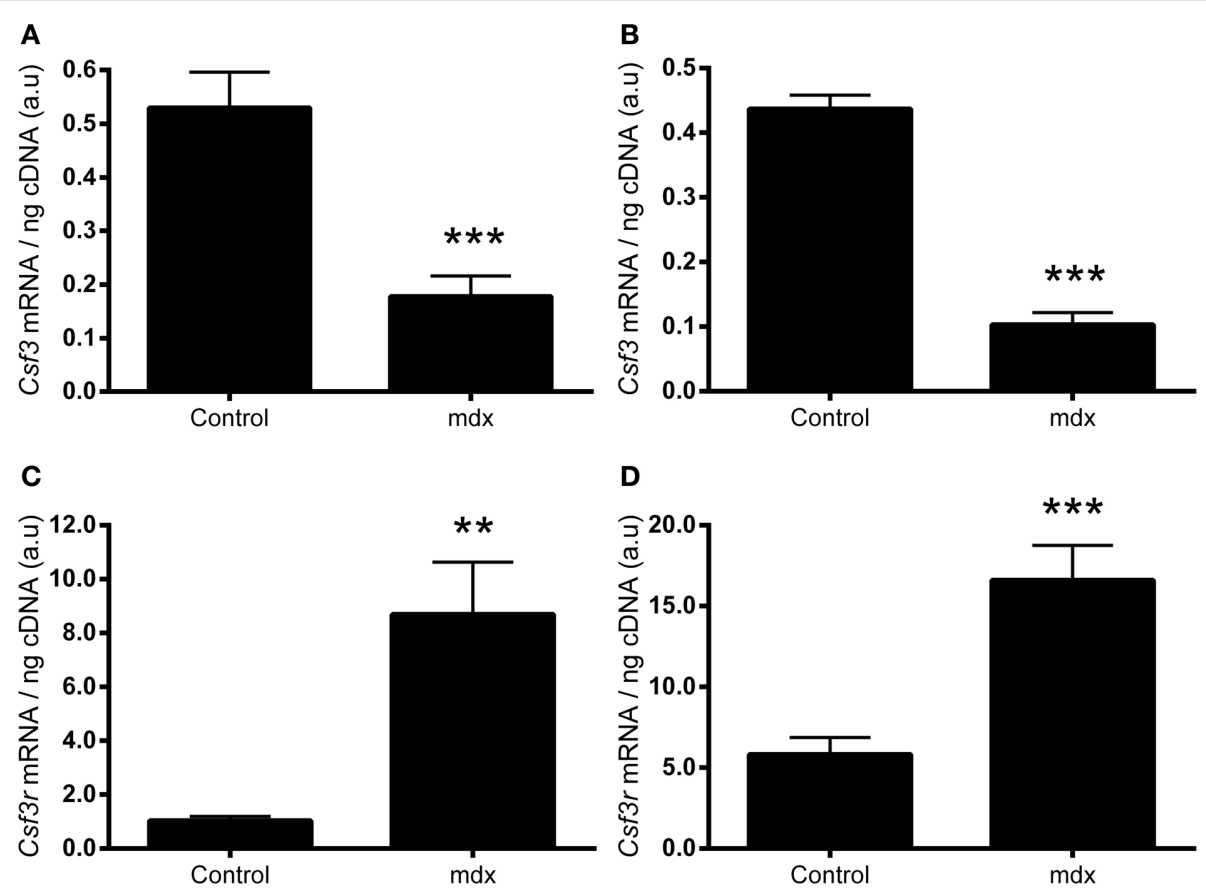

FIGURE 3 | mRNA expressions of G-CSF and G-CSFR mRNA in muscles from $\boldsymbol{m} \boldsymbol{d} \boldsymbol{x}$ mice. (A) G-CSF (Csf3) mRNA in the tibialis anterior (TA) muscle. (B) G-CSF (Csf3) mRNA in the diaphragm. (C) G-CSFR
(Csf3r) mRNA in the TA and (D) G-CSFR (Csf3r) mRNA in the diaphragm. mRNA was normalized to cDNA content. ${ }^{* *} p<0.01$ and ${ }^{* * *} p<0.001$ ( $n=10$ per group). 
A

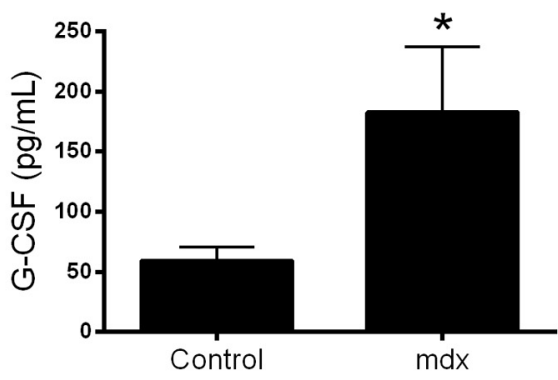

c tibialis anterior

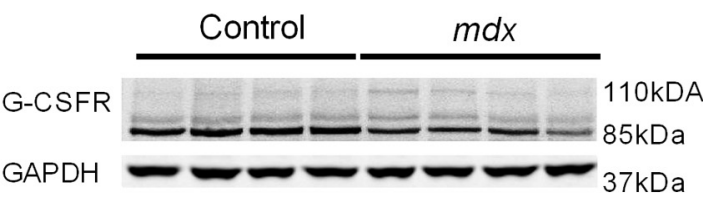

B

D
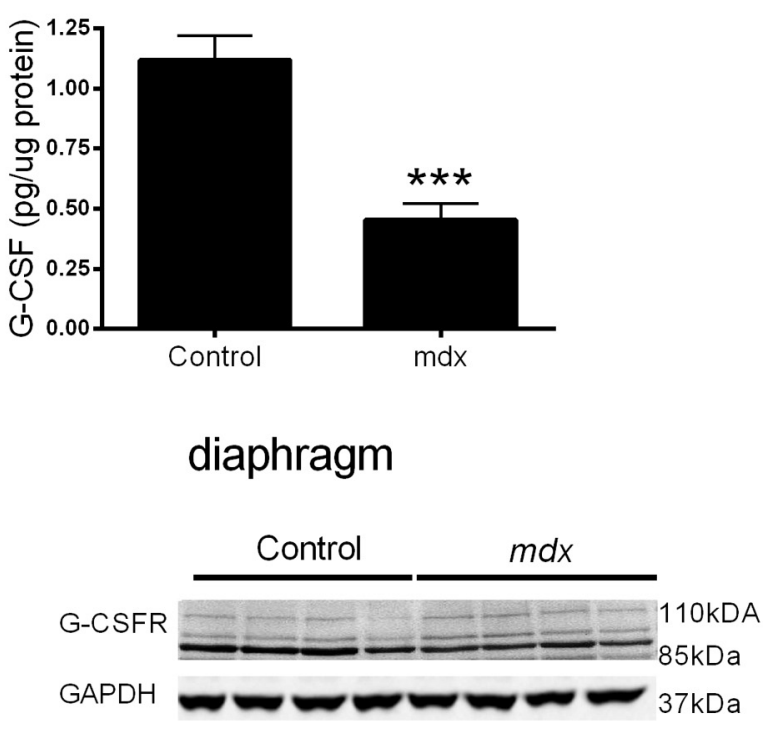

\section{diaphragm}

FIGURE 4 | G-CSF and G-CSFR protein expression in muscles from $\mathbf{m d x}$ mice. (A) Circulating plasma G-CSF levels. (B) G-CSF levels in the diaphragm homogenate. (C) Representative western blot images for the G-CSFR in the tibialis anterior muscle and band densitometry analysis and (D) Representative

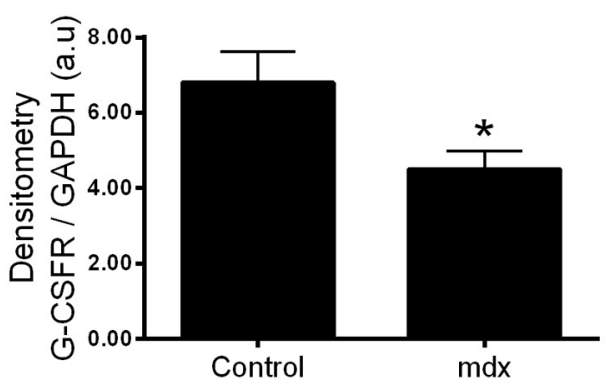

western blot images for the G-CSFR in the diaphragm muscles from $m d x$ mice and littermate controls and band densitometry analysis. ${ }^{*} p<0.05$ and ${ }^{* * *} p<0.001$. Cytokine analysis $(n=10)$, Western Blotting $(n=8)$ NB: G-CSF protein was undetectable in the TA muscle homogenate. effect of replenishing the media we compared cells treated with fresh media containing G-CSF $(40 \mathrm{ng} / \mathrm{ml})$ to those treated with fresh media containing vehicle only. G-CSF did not increase Akt or Erk1/2 phosphorylation above that of the vehicle treated cells (Figure 8). To confirm G-CSF was not affecting intracellular signaling protein in $\mathrm{C} 2 \mathrm{C} 12$ myoblasts we used a "spike in" method in which $20 \mu \mathrm{l} \mathrm{G-CSF}$ was added directly to the well containing serum free media to a final concentration of $40 \mathrm{ng} / \mathrm{ml}$. When G-CSF was "spiked in" no changes in Akt, STAT3, or Erk1/2 phosphorylation were observed, in contrast to an insulin control (Figure 9).

\section{DISCUSSION}

G-CSF treatment improves recovery of mouse skeletal muscle after crush injury or myotoxic damage and improves muscle function in mouse models of ALS (Stratos et al., 2007; Pitzer et al., 2008; Hara et al., 2011). However, the molecular mechanisms responsible for this improvement in muscle function are unknown. G-CSFR expression has been observed on various cell types outside of the haematopoietic system leading to speculation that G-CSFR may be expressed in skeletal muscle.
Consequently, G-CSF may directly bind to G-CSFR activating intramuscular signaling pathways involved in tissue repair. Therefore, the present study aimed to establish and characterize G-CSF and G-CSFR expression in proliferating, differentiating or fully differentiated $\mathrm{C} 2 \mathrm{C} 12$ muscle cells, human primary muscle cells and in mature mouse and human muscle. Since G-CSF and G-CSFR levels are altered in various diseases (Ninci et al., 2000; Chakraborty and Guha, 2007; Pitzer et al., 2008, 2010; Hsu et al., 2013), the study also sought to characterize whether G-CSF and G-CSFR expressed was perturbed in dystrophic skeletal muscle. Lastly, we sought to elucidate the molecular mechanisms by which G-CSF exerts its effects in $\mathrm{C} 2 \mathrm{C} 12$ myotubes. G-CSFR expression was confirmed in $\mathrm{C} 2 \mathrm{C} 12$ myoblasts with several novel observations. Firstly, G-CSFR mRNA and protein was identified in mouse $\mathrm{C} 2 \mathrm{C} 12$ and human primary myoblasts and myotubes and in mature skeletal muscle. Secondly, G-CSF mRNA was down-regulated in the diaphragm and TA muscles, while protein expression was down-regulated in the diaphragm and indeed undetectable in the TA muscles of $m d x$ mice compared with wild type mice. In contrast, the G-CSFR mRNA levels were increased, while G-CSFR protein levels were decreased in 


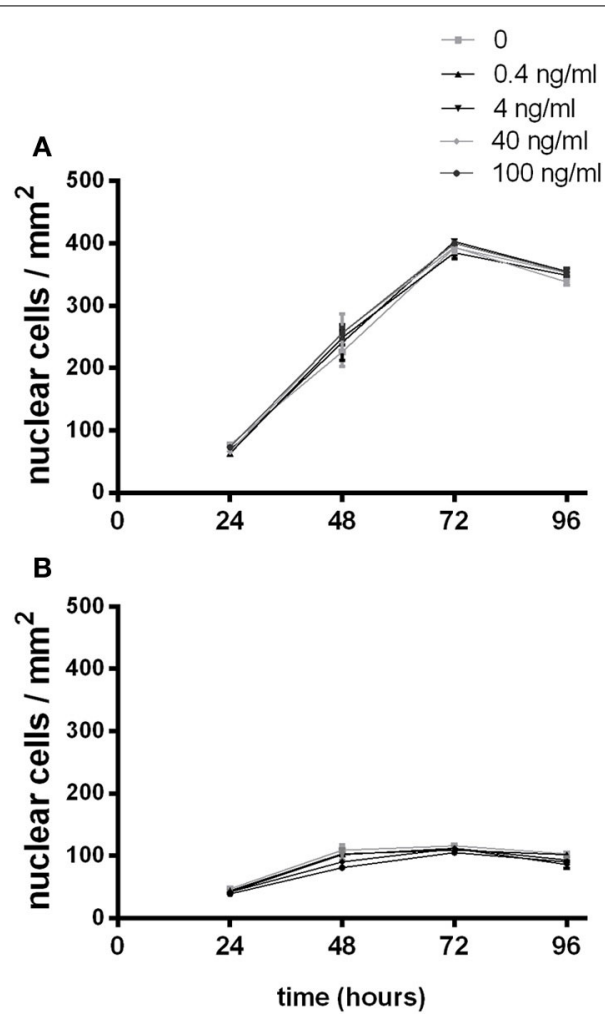

FIGURE 5 | The effects of G-CSF treatment on C2C12 myoblast proliferation. Proliferating $\mathrm{C} 2 \mathrm{C} 12$ myoblasts incubated in the presence of the indicated concentration of G-CSF under (A) normal growth media containing $10 \%$ fetal bovine serum or (B) serum depleted growth media containing $2 \%$ BSA. Data represents the mean \pm SEM taken from a minimum of 10 images per sample $(n=3)$.

both the diaphragm and the TA muscles of $m d x$ mice. Lastly, G-CSF treatment of C2C12 muscle cells did not increase proliferation, differentiation or intracellular activation of Akt, STAT3, and $\operatorname{Erk} 1 / 2$.

The identification of G-CSFR outside of tissues of haematopoietic origin has significant clinical relevance. Identifying G-CSFR in cardiac myocytes (Harada et al., 2005) has seen the administration of recombinant G-CSF progress from rodent models (Li et al., 2006; Takano et al., 2006, 2007; Ueda et al., 2006) to human clinical trials as a therapy to combat cardiac remodeling post infarction (Takano et al., 2007). The present study identified G-CSFR expression at both the mRNA and protein levels in proliferating $\mathrm{C} 2 \mathrm{C} 12$ myoblasts, as well as in terminally differentiated $\mathrm{C} 2 \mathrm{C} 12$ myotubes, human primary skeletal myoblast and myotube cultures and mature skeletal muscles from mice and humans. Our results support a recent report that G-CSFR protein is expressed in proliferating $\mathrm{C} 2 \mathrm{C} 12$ myoblasts (Hara et al., 2011), although there were also several important differences with that study. We show that G-CSFR is expressed in both myoblasts and myotubes, as well as muscle tissue, with multiple protein bands detected between $85 \mathrm{kDa}$ and $110 \mathrm{kDa}$ by Western blot. In contrast, Hara et al. detected a single band for the G-CSFR at $110 \mathrm{kDa}$ in $\mathrm{C} 2 \mathrm{C} 12$ myoblasts but not in differentiated myotubes (Hara et al., 2011). Moreover, positive and negative controls known to express/not express the G-CSFR were not used to show antibody specificity (Hara et al., 2011). This is important, since many G-CSFR antibodies have been proven to lack specificity in Western blotting and immunofluorescence (Debruin et al., 2010). In support of our data, similar multiple G-CSFR bands have been observed in mouse bone marrow which highly expresses G-CSFR (Hermans et al., 1998), and in our positive control, the murine pro-B cell line overexpressing G-CSFR. In addition, expression was confirmed by RT-PCR followed by sequencing of the product. This demonstrates definitively that G-CSFR is expressed in myoblasts, as well as differentiating and terminal myotubes, suggesting that G-CSF may have potential to aid in muscle regeneration as well as protecting against muscle loss by acting on mature muscle fibers.

Both G-CSF and G-CSFR are modulated in neural tissue of several disease models characterized with muscle atrophy and dysfunction, such as ALS patients and rodent models of ALS and spinal cord injury (Pitzer et al., 2008, 2010; Kawabe et al., 2011). Similar to these models, we observed perturbations in the expression of G-CSF and G-CSFR in the muscles of $m d x$ mice, a widely studied model for human DMD (Schertzer et al., 2008; Stupka et al., 2008). In $m d x$ mice, G-CSF mRNA was reduced in the TA muscles and diaphragm, while G-CSF protein was reduced in the diaphragm. G-CSFR expression was increased, as shown by mRNA. However, plasma G-CSF was raised, probably as a result of inflammation induced by the muscle damage (Hirose et al., 2004; Paulsen et al., 2005). This can ligate with its receptor, thereby degrading it in the lysosome and proteasome (Irandoust et al., 2007; Kindwall-Keller et al., 2008), leading to a decrease in G-CSFR protein. One corollary of this scenario would be that perhaps G-CSFR is already providing protective signals in the $m d x$ mouse, with symptoms potentially worsened if GCSFR was ablated. However, the importance of these observations remains unknown and warrants further investigation. G-CSF treatment in ALS mice increases muscle mass, muscle function and survival (Pitzer et al., 2008). ALS mice have increased G-CSF and G-CSFR levels in neural tissue suggesting their elevation may be an attempted "survival" mechanism for damaged neurons and for subsequent preservation of neural innervated muscles.

The present study demonstrated that G-CSF does not stimulate $\mathrm{C} 2 \mathrm{C} 12$ myoblast proliferation in the presence or absence of serum. Importantly, our C2C12 myoblasts doubled approximately every $24 \mathrm{~h}$ in serum, and exhibited a block in proliferation without serum, consistent with other studies (Yaffe and Saxel, 1977). In contrast, in the study by Hara et al showing G-CSF treatment increased $\mathrm{C} 2 \mathrm{C} 12$ myoblast proliferation they observed a reduction in myoblast cell number in the first $48 \mathrm{~h}$ in the control group (Hara et al., 2011), which may indicate cell cycle arrest and induction of differentiation (Walsh and Perlman, 1997). They also did not clearly describe if proliferation was measured in the presence or absence of serum, nor was the level of cell confluence at the time of treatment with G-CSF stated (Hara et al., 2011), making their results difficult to interpret. Myosin heavy chain proteins regulate skeletal muscle contraction and their mRNA levels are significantly increased during myogenesis (Brown et al., 2012). 


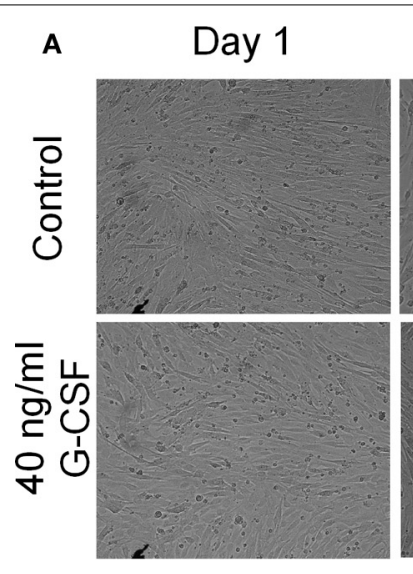

B

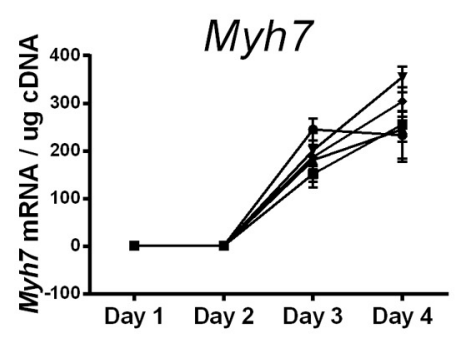

D

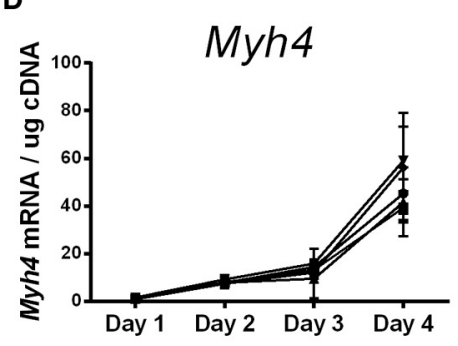

FIGURE 6 | The effects of G-CSF treatment on expression of Myh genes during $\mathbf{C 2 C 1 2}$ cell differentiation. (A) Light microscope images of $\mathrm{C} 2 \mathrm{C} 12$ cells at $24 \mathrm{~h}$ intervals during differentiation under normal conditions and in the presence of $40 \mathrm{ng} / \mathrm{ml}$ G-CSF. (B) Myh7 (C)

Day 2
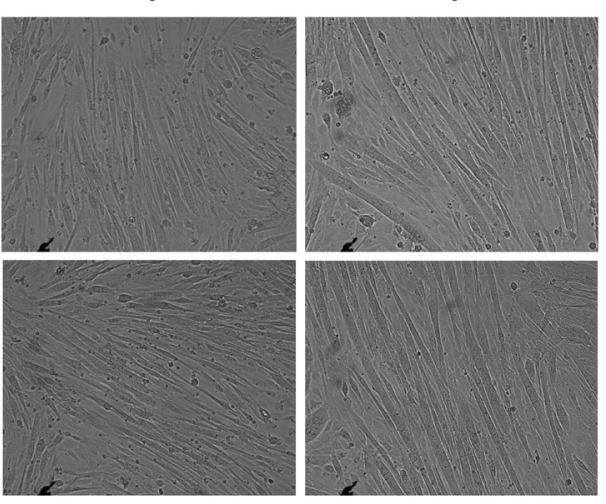

C

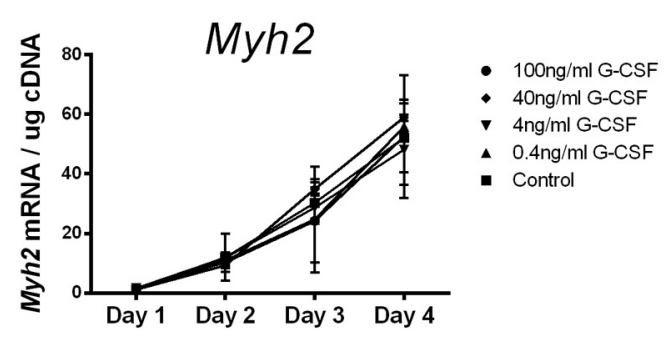

E

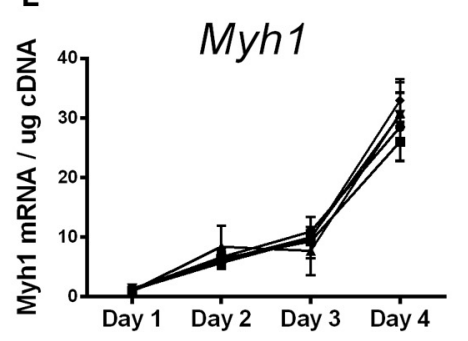

Myh2 (D) Myh4, and (E) Myh1 mRNA expression during 4 days of differentiation with $0,0.4,4,40$, and $100 \mathrm{ng} / \mathrm{ml} \mathrm{G-CSF}$. Data is represented as mean \pm SEM of the fold change compared to the Day 1 control $(n=3)$.
In the current study mRNA expression levels for myosin heavy chains (Myh-7, -4, -2 and -1) continued to increase throughout differentiation. G-CSF had no influence on the mRNA levels of these genes at any time point nor did G-CSF influence the myogenic regulatory factors MyoD and myogenin. This further supports our observation that G-CSF does not increase $\mathrm{C} 2 \mathrm{C} 12$ myoblast proliferation or differentiation.

G-CSF is known to activate Akt, STAT3, and Erk1/2 in cells expressing the G-CSFR (Chakraborty and Tweardy, 1998; Dong and Larner, 2000). Serum starving (3-20 h) prior to experimental treatment is used routinely to reduce basal cellular activity (Rommel et al., 2001; Stitt et al., 2004). Following re-stimulation with fresh media with and without G-CSF there was a significant increases in protein phosphorylation. However, there was no difference between the vehicle control and the G-CSF treated groups, demonstrating the media changes alone were sufficient to produce these changes. To confirm G-CSF was not affecting protein phosphorylation, G-CSF was spiked into the media so that the media was not removed from the cells. This alternative approach also revealed that G-CSF did not increase Akt, STAT3, or Erk1/2 phosphorylation in $\mathrm{C} 2 \mathrm{C} 12$ myoblasts. Without the necessary controls, the increased protein phosphorylation observed following media change could be mistaken as an effect of G-CSF treatment, especially given the strong rationale and prior observations (Hara et al., 2011). However, the results of the present study show that a media change alone is sufficient to stimulate Akt, STAT3, and Erk1/2, indicating that G-CSF does not activate these signaling proteins in $\mathrm{C} 2 \mathrm{C} 12$ muscle cells.

In conclusion, we show that the G-CSFR is expressed not just in myoblasts, but also in differentiated $\mathrm{C} 2 \mathrm{C} 12$ and human primary myotubes and mature mouse and human muscles. These findings suggest that the G-CSF ligand may act directly 

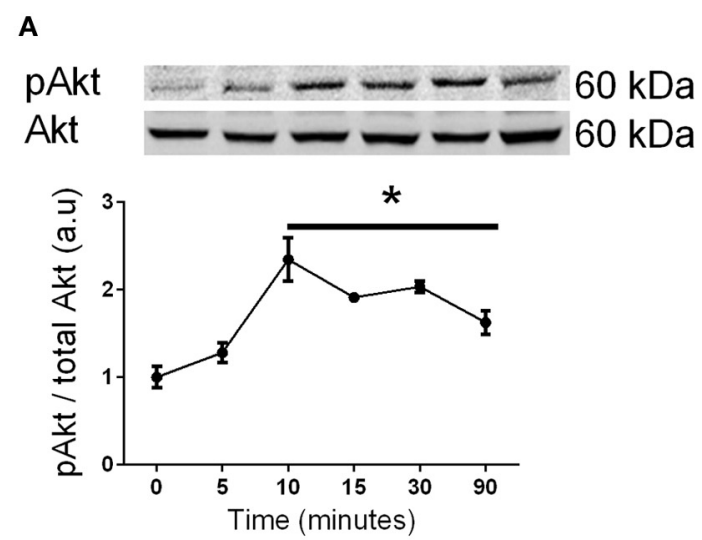

B
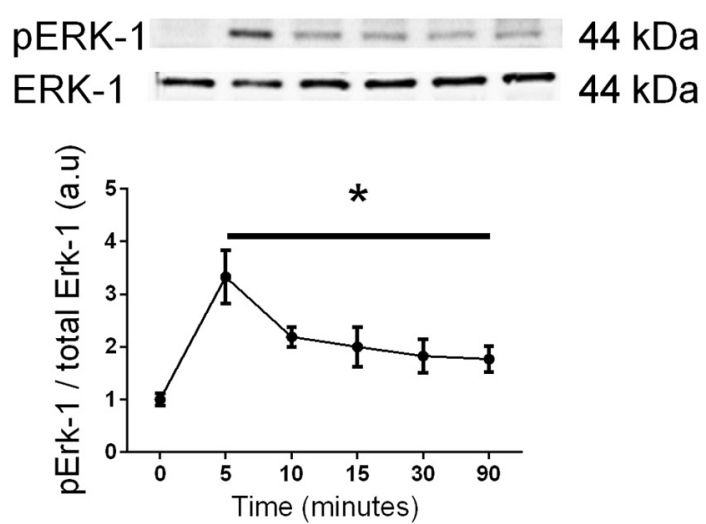

C

pERK-2 - - - - - $42 \mathrm{kDa}$ ERK-2 - - - - - $42 \mathrm{kDa}$

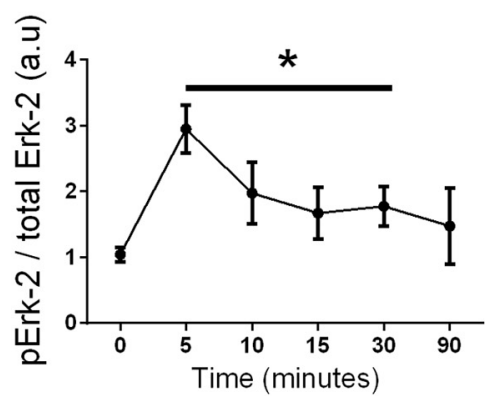

FIGURE 7 | The effects of changing media on Akt and Erk1/2 phosphorylation in C2C12 myoblasts. Western blot analysis using phospho-specific and control antibodies for (A) Akt, (B) Erk-1, and (C) Erk-2 after replenishing the media. Each panel shows a representative western blot above a graph of the fold-change, presented as mean \pm SEM compared to time zero $\left(n=3,{ }^{*} p<0.05\right)$.

on skeletal muscle via its receptor. We also show that G-CSF and the G-CSFR are reduced in the TA and diaphragm muscles from $m d x$ mice. The relevance of altered G-CSF/G-CSFR in the muscles of $m d x$ mice needs to be investigated to determine a causative, passive role in disease progression or whether G-CSF/G-CSFR is actively signaling to cause reduced G-CSFR
A
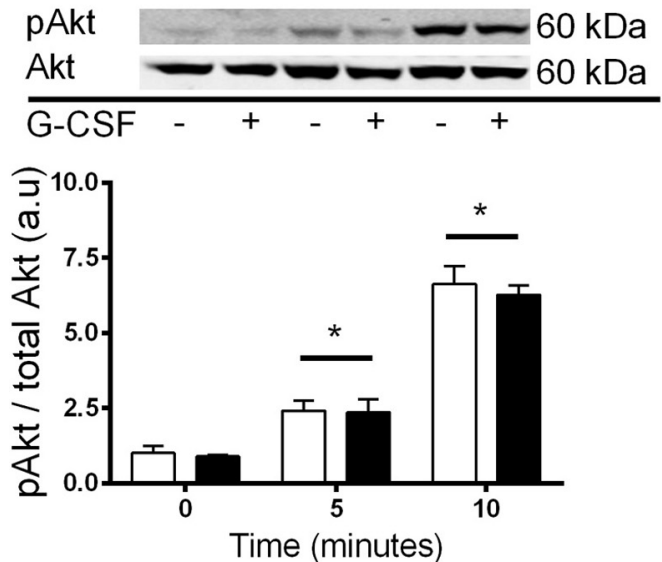

B
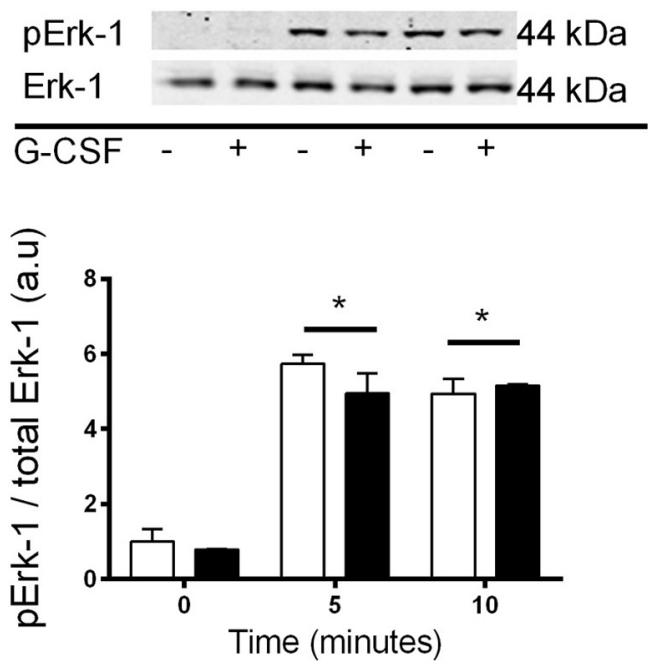

C
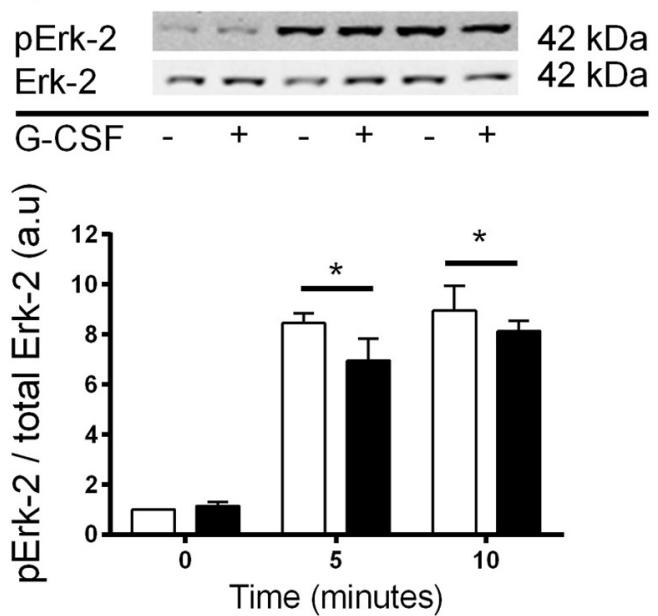

FIGURE 8 | Akt and Erk1/2 phosphorylation with 40 ng/ml G-CSF vs. vehicle treatment in myoblasts. Fold changes in phosphorylation for (A) Akt (B) Erk-1, and (C) Erk-2 after treatment with fresh media containing $40 \mathrm{ng} / \mathrm{ml} \mathrm{G-CSF}$ (black bars) or vehicle control (white bars). Data is shown as mean \pm SEM compared to time zero $\left(n=3,^{*} p<0.05\right)$. 


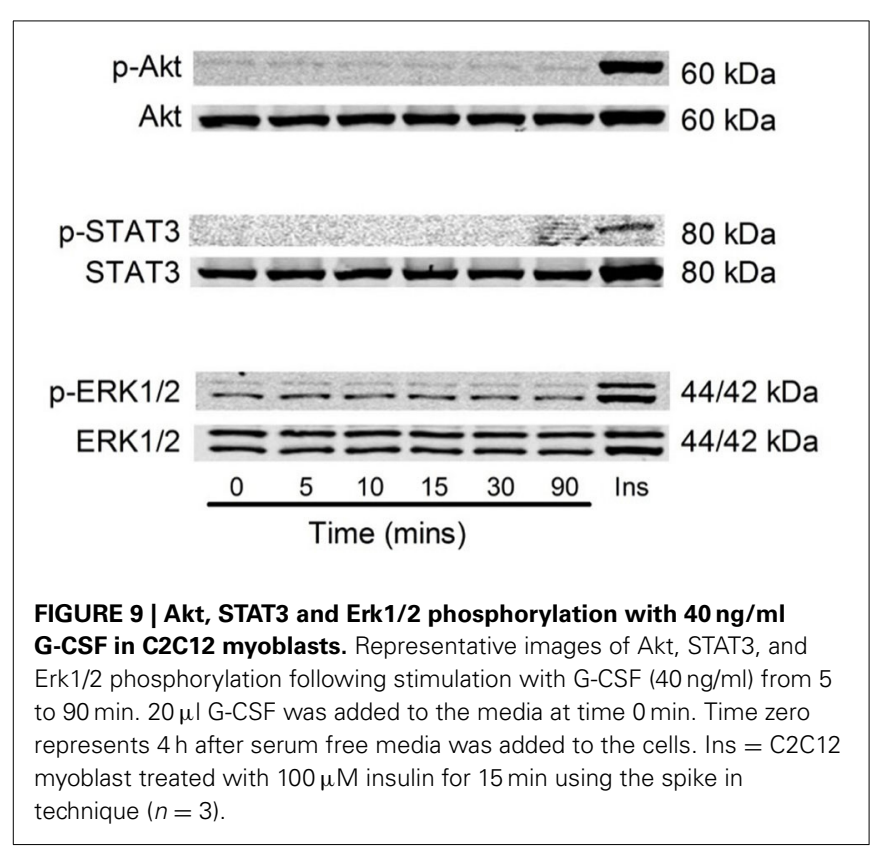

levels. However, since G-CSF treatment increases muscle recovery in various rodent models of trauma and/or disease, a reduction in G-CSF within the muscle suggests G-CSF may be protective against damage, or that elevating intramuscular G-CSF promote muscle regeneration. Therefore, G-CSF may have therapeutic potential for managing the pathophysiology of muscular dystrophy.

The molecular mechanisms by which G-CSF exerts its effects remain elusive as the current study demonstrates that G-CSF does not increase myoblast proliferation with concentrations ranging from 0.4 to $100 \mathrm{ng} / \mathrm{ml}$. The actions of G-CSF may therefore require the interaction with other cytokines and growth factors in vivo. For example G-CSF is known to cooperate with stem cell factor in haematopoiesis (Duarte and Franf, 2002) and IL-6 during bone marrow stem cell tumour progression (Yan et al., 2013). Alternatively, it may act directly on other cell populations, such as immune cells to stimulate the release of factors that are able to act directly on muscle cells. Furthermore, we showed that G-CSF does not increase Akt, STAT3, or Erk1/2 above that caused by replenishing media. This highlights the importance of using rigorous controls, meaning those studies lacking such controls should be interpreted with caution.

\section{SUPPLEMENTARY MATERIAL}

The Supplementary Material for this article can be found online at: http://www.frontiersin.org/journal/10.3389/fphys.2014. 00170/abstract

Supplementary Figure 1 | BrDU incorporation into proliferating C2C12 myoblasts following G-CSF treatment. Proliferating $\mathrm{C} 2 \mathrm{C} 12$ myoblasts in Growth Media (GM) containing DMEM + 10\% FBS (black bars) or $\mathrm{DMEM}+2 \%$ BSA (white bars) following $0,0.4,4,40$, and $100 \mathrm{ng} / \mathrm{ml}$ G-CSF treatment for (1) $24 \mathrm{~h}$ and (2) $48 \mathrm{~h}$. Data is Mean $\pm \mathrm{SEM}, n=8$, $* p<0.05$ compared to GM.
Supplementary Figure 2 | DAPI staining of proliferating C2C12 myoblast following G-CSF stimulation grown in $\mathbf{1 0} \%$ FBS. Representative images following DAPI staining of C2C12myoblastsfollowing 24, 48, 72, and $96 \mathrm{~h}$ in DMEM $+10 \%$ FBS with the indicated concentration of G-CSF. A minimum of 10 images were obtained per sample $(n=3)$.

Supplementary Figure 3 | DAPI staining of proliferating C2C12 myoblasts following G-CSF treatment with serum depletion. Representative images following DAPI staining of C2C12myoblastsfollowing 24, 48, 72, and $96 \mathrm{~h}$ in DMEM $+2 \%$ BSA with the indicated concentration of G-CSF. A minimum of 10 images were obtained per sample $(n=3)$.

\section{REFERENCES}

Bergstrom, J. (1975). Percutaneous needle biopsy of skeletal muscle in physiological and clinical research. Scand. J. Clin. Lab. Invest. 35, 609-616. doi: 10.3109/00365517509095787

Brown, D. M., Parr, T., and Brameld, J. M. (2012). Myosin heavy chain mRNA isoforms are expressed in two distinct cohorts during C2C12 myogenesis. J. Muscle Res. Cell Motil. 32, 383-390. doi: 10.1007/s10974-011-9267-4

Chakraborty, A., and Guha, S. (2007). Granulocyte colony-stimulating factor/granulocyte colony-stimulating factor receptor biological axis promotes survival and growth of bladder cancer cells. Urology 69, 1210-1215. doi: 10.1016/j.urology.2007.02.035

Chakraborty, A., and Tweardy, D. J. (1998). Stat3 and G-CSF-induced myeloid differentiation. Leuk. Lymphoma 30, 433-442.

Chakraborty, A., White, S. M., and Guha, S. (2006). Granulocyte colonystimulating receptor promotes betal-integrin-mediated adhesion and invasion of bladder cancer cells. Urology 68, 208-213. doi: 10.1016/j.urology.2006. 01.046

Chakraborty, A., White, S. M., and Lerner, S. P. (2004). Granulocyte colonystimulating factor receptor signals for betal-integrin expression and adhesion in bladder cancer. Urology 63, 177-183. doi: 10.1016/S0090-4295(03)00786-6

Dal-Re, R. (2011). Worldwide clinical interventional studies on leading causes of death: a descriptive analysis. Ann. Epidemiol. 21, 727-731. doi: 10.1016/j.annepidem.2011.03.010

Debruin, C., Lincoln, P., Hartley, C., Shehabeldin, A., Van, G., and Szilvassy, S. J. (2010). Most purported antibodies to the human granulocyte colonystimulating factor receptor are not specific. Exp. Hematol. 38, 1022-1035. doi: 10.1016/j.exphem.2010.07.011

Dong, F., and Larner, A. C. (2000). Activation of Akt kinase by granulocyte colonystimulating factor (G-CSF): evidence for the role of a tyrosine kinase activity distinct from the Janus kinases. Blood 95, 1656-1662.

Duarte, R. F., and Franf, D. A. (2002). The synergy between stem cell factor (SCF) and granulocyte colony-stimulating factor (G-CSF): molecular basis and clinical relevance. Leuk. Lymphoma 43, 1179-1187. doi: 10.1080/10428190290026231

Evans, W. J., Phinney, S. D., and Young, V. R. (1982). Suction applied to a muscle biopsy maximizes sample size. Med. Sci. Sports Exerc. 14, 101-102.

Gehrig, S. M., van der Poel, C., Sayer, T. A., Schertzer, J. D., Henstridge, D. C., Church, J. E., et al. (2012). Hsp72 preserves muscle function and slows progression of severe muscular dystrophy. Nature 484, 394-398. doi: 10.1038/nature10980

Hara, M., Yuasa, S., Shimoji, K., Onizuka, T., Hayashiji, N., Ohno, Y., et al. (2011). G-CSF influences mouse skeletal muscle development and regeneration by stimulating myoblast proliferation. J. Exp. Med. 208, 715-727. doi: 10.1084/jem.20101059

Harada, M., Qin, Y., Takano, H., Minamino, T., Zou, Y., Toko, H., et al. (2005). G-CSF prevents cardiac remodeling after myocardial infarction by activating the Jak-Stat pathway in cardiomyocytes. Nat. Med. 11, 305-311. doi: 10.1038/nm1199

Hermans, M. H., Ward, A. C., Antonissen, C., Karis, A., Lowenberg, B., and Touw, I. P. (1998). Perturbed granulopoiesis in mice with a targeted mutation in the granulocyte colony-stimulating factor receptor gene associated with severe chronic neutropenia. Blood 92, 32-39.

Hirose, L., Nosaka, K., Newton, M., Laveder, A., Kano, M., Peake, J., et al. (2004). Changes in inflammatory mediators following eccentric exercise of the elbow flexors. Exerc. Immunol. Rev. 10, 75-90. 
Hsu, D. M., Agarwal, S., Benham, A., Coarfa, C., Trahan, D. N., Chen, Z., et al. (2013). G-CSF receptor positive neuroblastoma subpopulations are enriched in chemotherapy-resistant or relapsed tumors and are highly tumorigenic. Cancer Res. doi: 10.1158/0008-5472.CAN-12-4056

Irandoust, M. I., Aarts, L. H., Roovers, O., Gits, J., Erkeland, S. J., and Touw, I. P. (2007). Suppressor of cytokine signaling 3 controls lysosomal routing of G-CSF receptor. EMBO J. 26, 1782-1793. doi: 10.1038/sj.emboj.7601640

Jagoe, R. T., and Goldberg, A. L. (2001). What do we really know about the ubiquitin-proteasome pathway in muscle atrophy? Curr. Opin. Clin. Nutr. Metab. Care 4, 183-190. doi: 10.1097/00075197-200105000-00003

Kawabe, J., Koda, M., Hashimoto, M., Fujiyoshi, T., Furuya, T., Endo, T., et al. (2011). Neuroprotective effects of granulocyte colony-stimulating factor and relationship to promotion of angiogenesis after spinal cord injury in rats: laboratory investigation. J. Neurosurg. Spine 15, 414-421. doi: 10.3171/2011.5.SPINE10421

Kindwall-Keller, T. L., Druhan, L. J., Ai, J., Hunter, M. G., Massullo, P., Loveland, M., et al. (2008). Role of the proteasome in modulating native G-CSFR expression. Cytokine 43, 114-123. doi: 10.1016/j.cyto.2008.04.015

Kirsch, F., Kruger, C., and Schneider, A. (2008). The receptor for granulocyte-colony stimulating factor (G-CSF) is expressed in radial glia during development of the nervous system. BMC Dev. Biol. 8:32. doi: 10.1186/1471213X-8-32

Kumar, J., Fraser, F. W., Riley, C., Ahmed, N., McCulloch, D. R., and Ward, A. C. (2014). Granulocyte colony-stimulating factor receptor signalling via Janus kinase 2/signal transducer and activator of transcription 3 in ovarian cancer. $B r$. J. Cancer 110, 133-145. doi: 10.1038/bjc.2013.673

Li, L., Takemura, G., Li, Y., Miyata, S., Esaki, M., Okada, H., et al. (2007). Granulocyte colony-stimulating factor improves left ventricular function of doxorubicin-induced cardiomyopathy. Lab. Invest. 87, 440-455. doi: 10.1038/labinvest. 3700530

Li, Y., Takemura, G., Okada, H., Miyata, S., Esaki, M., Maruyama, R., et al. (2006). Treatment with granulocyte colony-stimulating factor ameliorates chronic heart failure. Lab. Invest. 86, 32-44. doi: 10.1038/labinvest.3700367

Murray, C. J., and Lopez, A. D. (1997). Mortality by cause for eight regions of the world: global burden of disease study. Lancet 349, 1269-1276. doi: 10.1016/S0140-6736(96)07493-4

Nagata, S., and Fukunaga, R. (1991). Granulocyte colony-stimulating factor and its receptor. Prog. Growth Factor Res. 3, 131-141. doi: 10.1016/S09552235(05)80004-3

Naito, T., Goto, K., Morioka, S., Matsuba, Y., Akema, T., Sugiura, T., et al. (2009). Administration of granulocyte colony-stimulating factor facilitates the regenerative process of injured mice skeletal muscle via the activation of Akt/GSK3alphabeta signals. Eur. J. Appl. Physiol. 105, 643-651. doi: 10.1007/s00421-008-0946-9

Ninci, E. B., Brandstetter, T., Meinhold-Heerlein, I., Bettendorf, H., Sellin, D., and Bauknecht, T. (2000). G-CSF receptor expression in ovarian cancer. Int. J. Gynecol. Cancer 10, 19-26. doi: 10.1046/j.1525-1438.2000.99076.x

Oishi, A., Otani, A., Sasahara, M., Kojima, H., Nakamura, H., Yodoi, Y., et al. (2008). Granulocyte colony-stimulating factor protects retinal photoreceptor cells against light-induced damage. Invest. Ophthalmol. Vis. Sci. 49, 5629-5635. doi: 10.1167/iovs.08-1711

Paulsen, G., Benestad, H. B., Strã,M-Gundersen, I., Mã,Rkrid, L., Lappegã ¥Rd, K. T., and Raastad, T. (2005). Delayed leukocytosis and cytokine response to high-force eccentric exercise. Med. Sci. Sports Exerc. 37, 1877-1883. doi: 10.1249/01.mss.0000177064.65927.98

Piscaglia, A. C., Shupe, T. D., Oh, S.-H., Gasbarrini, A., and Petersen, B. E. (2007). Granulocyte-colony stimulating factor promotes liver repair and induces oval cell migration and proliferation in rats. Gastroenterology 133, 619-631. doi: 10.1053/j.gastro.2007.05.018

Pitzer, C., Klussmann, S., Kruger, C., Letellier, E., Plaas, C., Dittgen, T., et al. (2010). The hematopoietic factor granulocyte-colony stimulating factor improves outcome in experimental spinal cord injury. J. Neurochem. 113, 930-942. doi: 10.1111/j.1471-4159.2010.06659.x

Pitzer, C., Kruger, C., Plaas, C., Kirsch, F., Dittgen, T., Muller, R., et al. (2008). Granulocyte-colony stimulating factor improves outcome in a mouse model of amyotrophic lateral sclerosis. Brain 131, 3335-3347. doi: 10.1093/brain/awn243

Roberts, A. W. (2005). G-CSF: a key regulator of neutrophil production, but that's not all! Growth Factors 23, 33-41. doi: 10.1080/089771905000 55836
Rommel, C., Bodine, S. C., Clarke, B. A., Rossman, R., Nunez, L., Stitt, T. N., et al. (2001). Mediation of IGF-1-induced skeletal myotube hypertrophy by PI(3)K/Akt/mTOR and PI(3)K/Akt/GSK3 pathways. Nat. Cell Biol. 3, 1009-1013. doi: 10.1038/ncb1101-1009

Savarese, T. M., Mitchell, K., Mcquain, C., Campbell, C. L., Guardiani, R., Wuu, J., et al. (2001). Coexpression of granulocyte colony stimulating factor and its receptor in primary ovarian carcinomas. Cancer Lett. 162, 105-115. doi: 10.1016/S0304-3835(00)00623-6

Schertzer, J. D., van der Poel, C., Shavlakadze, T., Grounds, M. D., and Lynch, G. S. (2008). Muscle-specific overexpression of IGF-I improves E-C coupling in skeletal muscle fibers from dystrophic mdx mice. Am. J. Physiol. Cell Physiol. 294, C161-C168. doi: 10.1152/ajpcell.00399.2007

Shimoji, K., Yuasa, S., Onizuka, T., Hattori, F., Tanaka, T., Hara, M., et al. (2010). G-CSF promotes the proliferation of developing cardiomyocytes in vivo and in derivation from ESCs and iPSCs. Cell Stem Cell 6, 227-237. doi: 10.1016/j.stem.2010.01.002

Sinclair, A. M., Coxon, A., McCaffery, I., Kaufman, S., Paweletz, K., Liu, L., et al. (2010). Functional erythropoietin receptor is undetectable in endothelial, cardiac, neuronal, and renal cells. Blood 115, 4264-4272. doi: 10.1182/blood2009-10-248666

Stitt, T. N., Drujan, D., Clarke, B. A., Panaro, F., Timofeyva, Y., Kline, W. O., et al. (2004). The IGF-1/PI3K/Akt pathway prevents expression of muscle atrophyinduced ubiquitin ligases by inhibiting FOXO transcription factors. Mol. Cell 14, 395-403. doi: 10.1016/S1097-2765(04)00211-4

Stratos, I., Rotter, R., Eipel, C., Mittlmeier, T., and Vollmar, B. (2007). Granulocytecolony stimulating factor enhances muscle proliferation and strength following skeletal muscle injury in rats. J. Appl. Physiol. 103, 1857-1863. doi: 10.1152/japplphysiol.00066.2007

Stupka, N., Schertzer, J. D., Bassel-Duby, R., Olson, E. N., and Lynch, G. S. (2008). Stimulation of calcineurin Aalpha activity attenuates muscle pathophysiology in mdx dystrophic mice. Am. J. Physiol. Regul. Integr. Comp. Physiol. 294, R983-R992. doi: 10.1152/ajpregu.00375.2007

Tachibana, M., Miyakawa, A., Uchida, A., Murai, M., Eguchi, K., Nakamura, K., et al. (1997). Granulocyte colony-stimulating factor receptor expression on human transitional cell carcinoma of the bladder. Br. J. Cancer 75, 1489-1496. doi: 10.1038/bjc.1997.254

Takano, H., Qin, Y., Hasegawa, H., Ueda, K., Niitsuma, Y., Ohtsuka, M., et al. (2006). Effects of G-CSF on left ventricular remodeling and heart failure after acute myocardial infarction. J. Mol. Med. 84, 185-193. doi: 10.1007/s00109-0050035-Z

Takano, H., Ueda, K., Hasegawa, H., and Komuro, I. (2007). G-CSF therapy for acute myocardial infarction. Trends Pharmacol. Sci. 28, 512-517. doi: 10.1016/j.tips.2007.09.002

Tanaka, M., Kikuchi, H., Ishizu, T., Minohara, M., Osoegawa, M., Motomura, K., et al. (2006). Intrathecal upregulation of granulocyte colony stimulating factor and its neuroprotective actions on motor neurons in amyotrophic lateral sclerosis. J. Neuropathol. Exp. Neurol. 65, 816-825. doi: 10.1097/01.jnen.0000232025.84238.e1

Ueda, K., Takano, H., Hasegawa, H., Niitsuma, Y., Qin, Y., Ohtsuka, M., et al. (2006). Granulocyte colony stimulating factor directly inhibits myocardial ischemia-reperfusion injury through Akt-endothelial NO synthase pathway. Arterioscler. Thromb. Vasc. Biol. 26, e108-e113. doi: 10.1161/01.ATV.0000219697.99134.10

Wallace, M. A., Hock, M. B., Hazen, B. C., Kralli, A., Snow, R. J., and Russell, A. P. (2011). Striated muscle activator of Rho signalling (STARS) is a PGC$1 \alpha /$ oestrogen-related receptor- $\alpha$ target gene and is upregulated in human skeletal muscle after endurance exercise. J. Physiol. 589, 2027-2039. doi: 10.1113/jphysiol.2011.205468

Walsh, K., and Perlman, H. (1997). Cell cycle exit upon myogenic differentiation. Curr. Opin. Genet. Dev. 7, 597-602. doi: 10.1016/S0959-437X(97) 80005-6

Ward, A. C., Hermans, M. H., Smith, L., van Aesch, Y. M., Schelen, A. M., Antonissen, C., et al. (1999). Tyrosine-dependent and -independent mechanisms of STAT3 activation by the human granulocyte colony-stimulating factor (G-CSF) receptor are differentially utilized depending on G-CSF concentration. Blood 93, 113-124.

Yaffe, D., and Saxel, O. (1977). Serial passaging and differentiation of myogenic cells isolated from dystrophic mouse muscle. Nature 270, 725-727. doi: $10.1038 / 270725 \mathrm{a} 0$ 
Yan, B., Wei, J. J., Yuan, Y., Sun, R., Li, D., Luo, J., et al. (2013). IL-6 cooperates with G-CSF to induce protumor function of neutrophils in bone marrow by enhancing STAT3 activation. J. Immunol. 190, 5882-5893. doi: 10.4049/jimmunol.1201881

Yata, K., Matchett, G. A., Tsubokawa, T., Tang, J., Kanamaru, K., and Zhang, J. H. (2007). Granulocyte-colony stimulating factor inhibits apoptotic neuron loss after neonatal hypoxia-ischemia in rats. Brain Res. 1145, 227-238. doi: 10.1016/j.brainres.2007. 01.144

Conflict of Interest Statement: The authors declare that the research was conducted in the absence of any commercial or financial relationships that could be construed as a potential conflict of interest.
Received: 28 January 2014; accepted: 11 April 2014; published online: 01 May 2014. Citation: Wright CR, Brown EL, Della-Gatta PA, Ward AC, Lynch GS and Russell AP (2014) G-CSF does not influence C2C12 myogenesis despite receptor expression in healthy and dystrophic skeletal muscle. Front. Physiol. 5:170. doi: 10.3389/fphys. 2014.00170

This article was submitted to Striated Muscle Physiology, a section of the journal Frontiers in Physiology.

Copyright (C) 2014 Wright, Brown, Della-Gatta, Ward, Lynch and Russell. This is an open-access article distributed under the terms of the Creative Commons Attribution License (CC BY). The use, distribution or reproduction in other forums is permitted, provided the original author(s) or licensor are credited and that the original publication in this journal is cited, in accordance with accepted academic practice. No use, distribution or reproduction is permitted which does not comply with these terms. 